\title{
Madde iliş̧kili Psikotik Bozuklukların Tedavisinde Kullanılan Atipik Antipsikotikler
}

\author{
Atypical Antipsychotics in the Treatment of Substance-related Psychotic \\ Disorders
}

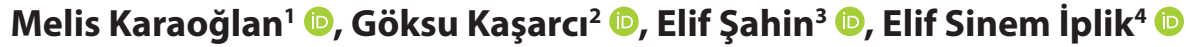 \\ ${ }^{1}$ İstanbul Yeni Yüzyıl Üniversitesi, Eczacılık Fakültesi, İstanbul, Türkiye \\ ${ }^{2}$ Istanbul Üniversitesi, Aziz Sancar Deneysel Tıp Araştırma Enstitüsü, Moleküler Tıp Anabilim Dalı, İstanbul, Türkiye \\ ${ }^{3}$ İstanbul Yeni Yüzyıl Üniversitesi, Eczacılık Fakültesi, Farmakoloji Anabilim Dalı, İstanbul, Türkiye \\ ${ }^{4}$ İstanbul Yeni Yüzyıl Üniversitesi, Eczacılık Fakültesi, Biyokimya Anabilim Dalı, İstanbul, Türkiye
}

ORCID ID: M.K. 0000-0003-4164-5991; G.K. 0000-0001-9766-4361; E.Ş. 0000-0002-0027-6723; E.S.I. 0000-0003-3465-1808

Cite this article as: Karaoğlan M, Kaşarcı G, Şahin E, Iplik ES. Atypical Antipsychotics in the Treatment of Substance Induced Psychotic Disorders. Experimed 2020; 10(1): 49-58.

\section{öz}

Son yıllarda madde ile ilişkili bozukluklar, madde bağımlılı̆ııın gittikçe yaygınlaşması ve madde kullanımının daha ileri dönemlerde kişinin sinir sistemi üzerinde yarattığı etkileri dolayısıyla önemli bir halk sağlığı sorunu haline gelmiştir. Maddenin yol açtığı bozukluklar temel olarak 2 gruba ayrılmaktadır; madde kullanım bozuklukları ve maddenin yol açtığı bozukluklar. Maddenin yol açtığı bozukluklar; maddenin intoksikasyonu, madde yoksunluğu ve maddenin yol açıı̆ı psikotik bozukluklar gibi diğer madde ilişkili bozukluklardır. Madde ilişkili psikotik bozuklukların ileriki dönemlerde şizofreni veya bipolar bozukluk gibi kronik psikotik bozukluklara dönüşme olasılığı, bozukluğun tanı ve tedavisinin oldukça önemli olduğunu gözler önüne sermektedir. İlgili vakalarda birincil psikotik bozukluk ve maddenin yol açtığı psikotik bozukluk ayrımlarının yapılması, doğru tanı ve etkin tedavi uygulamaları açısından önem arz etmektedir. Maddenin yol açtığı psikotik bozuklukların güncel tedavi seçenekleri arasında tipik (klasik) ve atipik antipsikotiklerin kullanımı yer almaktadır. Günümüzde, psikotik belirtiler üzerindeki olumlu etkilerinin yanı sıra; madde kullanma arzusu ve madde arayışını azaltmaları ve klasik antipsikotiklere oranla daha az ekstrapiramidal sistem yan etkilerine sahip olmaları sebebiyle atipik antipsikotikler ilk tercih edilen ilaç grubudur.

Bu derleme kapsamında madde ilişkili gelişen psikotik bozuklukların patogenezi ve farmakoterapide kullanılan atipik antipsikotiklerin güncel bilgiler ışığında tartışııması amaçlanmıştır..

Anahtar Kelimeler: Atipik antipsikotikler, madde ilişkili bozukluklar, psikotik bozukluk

\begin{abstract}
In recent years, substance-related disorders have become an important public health problem due to the effects of substance use on the nervous system later in life periods. Substance-related disorders are basically divided into two categories; substance use disorders and substance-induced disorders. Substance-related disorders consist of substance intoxication, substance withdrawal and other substance-induced disorders such as substance-induced psychotic disorders. The possibility of conversion of substance use disorders to chronic psychotic disorders such as schizophrenia, bipolar disease reveals the importance of its diagnosis and treatment. In related cases, it is important to make distinction between the primer psychotic disorder and substance related disorder for correct diagnosis and effective treatment. Current treatment options for psychotic disorders caused by the substance include the use of typical (classic) and atypical antipsychotics. Nowadays, atypical antipsychotics are the primary drug of choice in the treatment of substance-induced psychotic disorders, not only because of their positive impacts on psychotic symptoms but also because of their reducing effect on substance craving and seeking and fewer extrapyramidal side effects compared to typical antipsychotics.
\end{abstract}

This review aims to explain the pathogenesis of substance-related psychotic disorders and to discuss the atypical antipsychotics used in the treatment within the framework of current literature.

Keywords: Atypical antipsychotics, substance-related disorder, psychotic disorder 


\section{GíRiş}

Psikoz, Dünya Sağlık Örgütü (WHO) ve Amerikan Psikiyatri Birliği tarafından "içgörüsüz halüsinasyonlar veya sanrıların varlığı" olarak tanımlanmaktadır. Bu ortak tanımda yer alan "içgörü" ifadesi Aubrey Lewis tarafından "kişinin kendinde ortaya çıkan morbid değişiklikleri doğru biçimde algılayabilmesi" şeklinde açıklanmıştır (1). Psikiyatrik değerlendirmeler için önemli bir kavram olan içgörü özellikle şizofreni hastalarında hastalık belirtilerinin tanımlanması ve tedavi seyrinin takibi açısından oldukça değerlidir. WHO tarafından 1973 yılında yapılan şizofreni ile ilgili çalışmada psikotik bozukluk yaşayan bireylerin \%97'sinde içgörünün bulunmadığı belirlenmiştir (2).

Psikotik bozukluk vakalarında madde kullanım bozukluğuna sıkça rastlanmaktadır. Çeşitli çalışmalarda şizofreni veya bipolar bozukluk gibi ciddi psikotik bozukluğu bulunan bireyler arasında madde kullanım bozukluklarının daha yaygın olduğu ortaya koyulmuştur (3-5). Toplum genelinde madde kullanım bozukluğu \%15 oranla yaygınlık göstermekteyken; psikotik bozukluk vakalarının \%50'sinde yaşamlarının bir periyodunda madde kullanım bozukluğu görülmektedir (3).

Madde ile ilişkili bozukluklar ve psikiyatrik bozuklukların bir arada seyretmesi durumu; tanı ve tedaviyi zorlaştıran, hastanede yatış süresini uzatan, semptomların hafiflemesini geciktiren ve intihar girişimi riskini arttıran ciddi bir sağlık problemidir (6). Tedavinin başarısız sonuçlandığı vakaların büyük çoğunluğunda, bu durum her iki bozukluğun tedavisinin hastaya uygulanmamasıyla ilişkilendirilmiştir. Bu bağlamda ele alındığında, madde aracılı gelişen psikotik bozuklukların başarılı bir şekilde tedavi edilebilmesi için hem madde ile ilişkili bozukluğun hem de ruhsal bozukluğun tedavi edilmesi gerekmekte olup her problemin ayrı ayrı ele alındığı geleneksel yöntemler yerine bütüncül tedavi programları tercih edilmelidir. Bu bütüncül tedavi programı, farmakolojik tedavinin yanı sıra, içerisinde motivasyonel görüşme, kısa girişimler, bilişsel davranışçı terapi, edimsel yöntem ve kendine yardım gruplarının yer aldığı psikososyal yaklaşımlardan oluşmaktadır.

Günümüzde şizofreninin farmakolojik tedavisinde tipik antipsikotiklerin yerini alarak kullanılmakta olan atipik antipsikotikler, maddenin yol açtığı psikotik bozuklukların farmakolojik tedavisinde de tercih edilen bir ilaç grubudur. Atipik antipsikotik ilaçların, madde bağımlılığının gelişiminde rol oynadığı düşünülen ortak nöronal devre üzerinde etki göstermelerinin anlaşılması üzerine, bu ilaç grubunun madde bağımlılığı tedavisindeki etkisi araştırılmıştır. Psikoaktif maddelerin yol açtığı psikotik bozukluğun tedavisinde atipik antipsikotiklerin tercih edilmelerinin sebepleri; ortak nöronal devreye etkileri, dopamin $D_{2}$ reseptörü üzerine seçici etki göstermeleri, bilişsel fonksiyonlar üzerindeki olumlu etkileri, serotonin ve noradrenalin reseptörleri üzerindeki etkilerinin sonucu olarak duygu durum üzerindeki olumlu etkileri ve serotonin $5-\mathrm{HT}_{3}$ reseptörüne gösterdikleri afiniteyle ilişkilendirilen madde kullanma arzusunu azaltmalarıdır (7).

Bu derleme kapsamında; madde kullanımına bağlı olarak gelişen psikotik bozuklukların tedavisinde kullanılan atipik antipsi- kotik ilaçlar, bu ilaçların kullanım hedefleri ve etkilerinin güncel bilgiler ışığında tartışılması amaçlanmıştır.

\section{MADDE KAVRAMI VE TÜRLERI}

Bağımlılık yapan maddeler, merkezi sinir sistemini önemli derecede etkileyerek kişinin algılama, duygu durum, mental durum, davranış ve motor fonksiyonlarında bozukluk yapan psikoaktif maddeler olarak tanımlanmaktadır. "Psikoaktif madde" terimi yalnızca primer olarak beyni etkileyen maddeleri kapsadığı için; bağımlılığa veya kötüye kullanıma yol açabilecek ve beyni etkileme özelliğine sahip diğer maddeleri de kapsayabilecek bir terim olan "madde" günümüzde kabul görmektedir (8).

\section{Özgül Madde Türleri}

Amerikan Psikiyatri Birliği tarafından Mental Bozuklukların Tanısal ve istatistiksel El Kitabı'nın beşinci baskısı (Diagnostic and Statistical Manual of Mental Disorders Fifth Edition, DSM-V) kapsamında; uzun süreli kullanımları veya suistimal edilmeleri durumunda bireyde fizyolojik veya psikolojik olarak çeşitli bozukluklara yol açabilen maddeler on farklı sınıfta değerlendirilmiştir (Tablo 1) (8). Uyarıcı nitelikte farklı sınıflarda gruplandırılan bu maddeler, aşırı miktarda alınmaları durumunda beynin ödül sistemini direkt olarak aktive etmeleri açısından ortak özelliklere sahip olup ödül yolaklarını normal yollarla uyarıma göre daha hızlı ve etkin bir şekilde uyarmaktadırlar (9).

Tablo 1. DSM-V'e göre Özgül Madde Türleri (8)

\begin{tabular}{l}
\hline Alkol \\
\hline Kafein \\
\hline Kannabis \\
\hline Halüsinojen \\
\hline İnhalanlar \\
\hline Opiyat \\
\hline Sedatifler \\
\hline Stimulanlar \\
\hline Tütün \\
\hline Diğer
\end{tabular}

Amfetamin, kannabis, alkol ve diğer uyarıcı maddeler uzun süredir psikotojenik bileşenler olarak kabul edilmekle birlikte yapılan çeşitli çalışmalarda bu maddelerin kontrolsüz alımlarının kişide psikoz gelişiminde rol oynadığı ortaya koyulmuştur (10).

\section{Alkol}

Eski kültürlerden itibaren alkol, opiyat ile birlikte insan tarafından kullanılan ilk psikoaktif maddelerden biri olup günümüzde de birçok toplumda dini veya kültürel amaçlarla yaygın olarak kullanılmaktadır. Fizyolojik olarak metabolize edilmesi sırasında organizma üzerinde olumlu veya olumsuz çeşitli etkileri bulunmaktadır (11). 
Kullanım açısından en sık suistimal edilen psikoaktif maddelerden biri olan alkol; yoksunluk belirtileriyle birlikte intoksikasyon, deliryum tremens, Wernicke ensefalopatisi ve alkol halüsinozunun sebep olduğu ciddi psikotik bozukluklar gibi çeşitli klinik tablolara neden olabilmektedir. Bununla birlikte yapılan epidemiyolojik çalışmalara göre; çeşitli psikiyatrik bozukluklara sahip hastalardan; Bipolar Tip I hastalarının \%46'sı, Bipolar Tip II hastalarının \%39'u, şizofreni hastalarının \%34'ü, kişilik bozukluğuna sahip hastaların \%29'u ve major depresif bozukluğa sahip hastaların ise \%7'si bu bozukluklarla eş zamanlı olarak alkol kullanım bozukluğu tanısı da almıştır (11).

\section{Kafein}

Dünya üzerinde en yaygın kullanılan psikoaktif maddelerden biri olan kafein, çay ve kahvenin dışında, çikolata, kakao ve enerji içecekleri gibi pek çok farklı maddenin içerisinde de yer almaktadır. Tüm dünya genelinde kahve ve kafein içeren diğer yiyecek ve içecekler günlük diyetin önemli bir parçasını oluşturmaktadır (12). Diyetle alımını takiben hızla emilen ve dolaşıma katılan kafeinin merkezi sinir sistemi üzerindeki etkinliğinin benzodiazepin reseptörleri aracılığı ile serotonin ve nor-adrenalin salımının artırılması şeklinde olduğu düşünülmektedir (14). Ayrıca kafein adenozin $A_{1}$ ve $A_{2 A}$ reseptörlerinin yarışmalı antagonisti olarak da işlev göstermekte ve mezolimbik dopamin yolağında dopamin aktivitesini etkileyebilmektedir. Bu şekilde modüle edilen dopaminerjik sinyal iletiminin, kafeinin çeşitli psikotik belirtilerin de dahil olduğu davranış, algı ve düşünce süreçleri üzerindeki etkilerinin temelini oluşturduğu düşünülmektedir (12).

Yapılan farklı araştırmalar doğrultusunda kafein tüketimi ile psikotik bozukluk semptomlarının gelişimi arasındaki ilişki uzun zamandır bilinmektedir. Hedges ve ark. tarafından kafein kullanımının sağlıklı insanlarda psikoz gelişimini indukleyebildiği gösterilmiştir (13). Bununla paralel olarak bir başka çalışmada psikotik bozukluğu olan bireylerde kafein kullanımı ile birlikte psikotik semptomların giderek kötüleştiği kaydedilmiştir (14).

\section{Kannabis}

Kannabis (esrar) hint kenevirinden (Cannabis sativa) elde edilen bir madde olup 421 çeşit kimyasal içermektedir (15). İntoksikasyondan ve davranışsal değişikliklerden sorumlu psikoaktif etken maddesi tetrahidrokannabiolün (THC) delta-9 izomeridir. Esrar, alkol ve tütünle birlikte tüm dünyada sıklıkla kullanılan keyif verici maddelerin başında gelmekte ve kullanım sıklığı giderek artmaktadır.

16 yaşından önce kannabis kullanımı; kişilik bozuklukları, anksiyete bozukluğu ve depresyonun da içerisinde yer aldığı mental bozukluklara ve madde kullanım bozukluklarına yatkınlık riskini arttırmaktadır (48). Kannabis kullanmış tüm bireylerin yaklaşık \%9'unda, kullanıma ergenlikte başlayanlarda ise 6 kişiden 1 'inde kannabis kullanım bozukluğu gelişmektedir (16). Her gün kannabis kullandığını belirten kişilerin 1/4'ünden 1/2'sine kadar oranda kannabis kullanım bozukluğu geliştiği bildirilmiştir (17). Birleşmiş Milletler Uyuşturucu ve Suç Ofisi (UNODC)'nin 2018 yılı raporuna göre kannabisin kısa süreli etkileri arasında paranoya, psikoz ve motor koordinasyonda bozukluk bulunurken, uzun süreli veya ağır kullanımının etkileri arasında şizofreni de dahil olmak üzere artmış kronik psikotik bozukluk riski, kronik bronşit semptomları ve okul başarısında azalma yer almaktadır (16).

\section{Halüsinojenler}

Halüsinojenler; kişinin çevresi veya kendi düşünce ve duyguları hakkındaki farkındalığını değiştirebilen bir çeşit kimyasal gruptur. Çok eski kültürlerde dini veya mistik amaçlı olarak kullanılan halüsinojenler çeşitli mantar veya bitkilerden doğal olarak elde edilebildiği gibi sentetik olarak da üretilebilmektedir. Sentetik olarak üretilen ilk halüsinojen liserjik asit dietilamid (LSD)'dir. LSD, Albert Hofmann tarafından 1938 yılında üretilmesine rağmen psikoaktif etkileri ancak 5 yıl sonrasında anlaşılmıştır (18). Halüsinojenler oldukça büyük heterojen bir grup olmakla birlikte kimyasal benzerliklerine göre farklı alt sınıflara ayrılmışlardır (19). Organizmada, metabolize edilmelerini takiben, serotonin agonistleri şeklinde hareket ederek en nihayetinde kişide değişen gerçeklik algıları üretirler (19).

\section{Inhalanlar}

İnhalanlar, kişinin yalnızca soluma yoluyla alabildiği maddeleri kapsayan ve kişide psikoaktif etki gösteren uçucu maddelerdir. Bunlar arasında toluen, n-hekzan, trikloretilen, diklorometan, benzin ve bütan gibi yaygın kullanılan uçucu hidrokarbonlar yer almaktadır. Bu kimyasal maddeler ticari olarak; solventler, aerosol spreyler, tiner gibi incelticiler ve sıvı yakıtlar içerisinde olmak üzere 4 farklı formda satılır.

Çoğu inhalan madde, merkezi sinir sistemini yavaşlatma yoluyla etki gösterir. Sağlık üzerindeki kısa süreli etkileri konuşma bozukluğu, koordinasyon eksikliği, baş dönmesi ve halüsinasyonlar şeklinde gözlenirken uzun süreli kullanım durumlarında karaciğer ve böbrek hasarı, gecikmiş davranış gelişimi ve beyin hasarı gözlenebilmektedir. Çok yaygın olmamakla birlikte inhalanların tekrar tekrar kullanımları madde kullanım bozukluğuna ve buna bağlı olarak daha ileri dönemlerde çeşitli psikotik bozukluklara yol açabilmektedir (20).

\section{Opiyat}

Opiyat (afyon), haşhaştan elde edilen doğal alkaloidler ve bunların yarı sentetik bileşiklerini ifade etmekte olup opioidlerin bir alt kümesidir. Doğal opiyatlar arasında morfin ve kodein gibi yüksek etkili ağrı kesiciler yer alırken, yarı sentetik opiyatlar arasında hidrokodon, oksikodon ve eroin yer almaktadır. Dünya genelinde klinik kullanımda olan kimyasal olarak birbirinden farklı 20 çeşit opioid bulunmaktadır. Endüstriyel olarak gelişmiş ülkelerde kötüye kullanıma ve bağımlılığa en sık eşlik eden opioid madde eroindir. Eroinin dışında, güçlü analjezik etkileri dolayısıyla son 20 yılda kronik ağrı tedavisinde doktorlar tarafından da giderek daha fazla tercih edilmektedir (21).

Çeşitli çalışmalar opioidlerin pediatrik olarak tıbbi olmayan amaçlarla da kullanıldığına dikkat çekmekte ve bu durumun ilerleyen dönemlerde madde kullanımına bağlı gelişen bozukluklar açısından risk taşıdığını vurgulamaktadır (22).

\section{Madde ile İlişkili Bozukluklar, Epidemiyoloji ve Etiyolojisi} Madde ile ilişkili bozukluklar tüm dünya çapında yarattığı sorunlar nedeniyle önemli bir halk sağlığı sorunu olarak kabul 
edilmektedir. Dünya nüfusunun yaklaşık $\% 5,6$ 'sına karşılık gelen, 15-64 yaş aralığındaki 275 milyon kişinin 2016 yılında en az bir kez madde kullandığı ve ayrıca 31 milyon madde kullanıcısında tedavi edilmesi gereken madde kullanım bozukluklarının geliştiği belirlenmiştir (23). Dünya Sağlık Örgütü (WHO) 2015 yılında yaklaşık 450,000 kişinin madde kullanımı sonucu hayatını kaybettiğini ortaya koymuştur. Bu ölümlerin 167,750'sinin doğrudan madde kullanım bozukluklarından (çoğunlukla aşırı doz), geriye kalan ölümlerin ise dolaylı olarak madde kullanım bozuklukları ve bunun yanı sıra sağlıksız enjeksiyon uygulamaları sebebiyle bulaşan İnsan İmmün Yetmezlik Virüsü (HIV), Hepatit C gibi viral etkenlerden kaynaklandığı bildirilmiştir (23).

Birleşmiş Milletler Uyuşturucu ve Suç Ofisi (United Nations Office on Drugs and Crime, UNODC) tarafından yayınlanan 2018 raporunda; 2016 yılı içerisinde 192 milyon kannabis, 34 milyon opiyat, 21 milyon ekstazi, 34 milyon amfetamin ve reçeteli uyaran ve 18 milyon kokain kullanıcısı olduğu vurgulanmaktadır. Ayrıca, 130 ülkeden elde edilen veriler ışığında 2016 yılında çoğu öğrenci olan ve genel nüfusun yaklaşık \%5'ine karşılık gelen 1516 yaş aralığındaki 13,8 milyon gencin son 12 ayda en az bir kez kannabis kullandığı belirlenmiş olup birçok ülkede kannabisin hem genç popülasyon hem de genel popülasyon tarafından en yaygın kullanılan madde türü olduğu ortaya koyulmuştur (23).

Aşırı dozda madde kullanımı dolayısıyla gerçekleşen ölümler, 2016 yılında Amerika Birleşik Devletleri (ABD)'nde bir önceki yıla kıyasla \%21'lik bir artış göstermiş olup 63,632 kişinin bu sebeple hayatını kaybettiği rapor edilmiştir. 2016 yılında fentanil ve analoglarının aşıı dozda kullanımına bağlı ölümlerin Kanada'da ciddi sayılara ulaştığına dair veriler mevcuttur. Aşırı doz madde kullanımı ile ilişkili ölümlerdeki bu artışın nedeni olarak özellikle fentanil ve analoglarının illegal olarak 3,4-Methylenedioxymethamphetamine (MDMA veya ekstazi), eroin, kokain veya sentetik opioidlerin içerisinde ekleniyor olması öne sürülmüştür (23). Bu durum madde kullanııılarının, çoğu zaman kendilerini aşırı doz sonucu ölüme sürükleyen bu maddelerin içeriğinden habersiz bir şekilde hayatlarını kaybettiklerini ortaya koymaktadır.

Madde kötüye kullanımının ya da yatkınlığının cinsiyetler arasındaki farklılığına dair de pek çok çalışma yapılmış olup önceleri kadınlara oranla erkeklerde daha fazla gözlenen bu suistimal durumunun kadınlarda da giderek arttığı rapor edilmiştir (17). 1980'lerin başlarında yapılan bir çalışmada alkol kullanım bozukluğunun erkek/kadın oranı 5:1 olarak bildirilmişken daha güncel çalışmalar bu oranı 3:1 olarak kaydetmiştir (24). Buna ek olarak kadınlar erkeklere oranla daha az miktarda ve daha kısa periyotta madde kullansalar dahi, madde bağımlılığı tedavisine başladıkları zaman erkeklere kıyasla davranışsal, psikolojik ve sosyal problemlerin daha şiddetli olduğu klinik tablolar ile karşılaşılmaktadır (17).

Amerikan Psikiyatri Derneği tarafından DSM-V kapsamında değerlendirilen ve genişletilerek son halini alan madde ile ilişkili bozukluklar; madde kullanım bozuklukları ve madde kullanımının yol açtığı bozukluklar olmak üzere 2 grupta incelenmek- tedir (8). Madde kullanım bozukluğunun temel özelliği, bireyin madde ile ilişkili problemler yaşamasına rağmen madde kullanımına devam ettiğini gösteren bir dizi bilişsel, davranışsal ve fizyolojik semptomların gözlenmesidir (25). Maddenin yol açtığı bozukluklar ise, kişide madde kullanım öyküsü öncesinde psikotik bozukluk belirtilerinin gelişmemesi ve psikotik bozuklukların madde kullanımı sonucunda gelişmesi durumu olarak değerlendirilmektedir. Madde kullanımının yol açtığı bozukluklar; madde intoksikasyonu, madde yoksunluğu ve maddenin yol açtığı diğer bozukluklar alt başlıklarından oluşmaktadır:

Madde Intoksikasyonu: Aşııı madde kullanımının ardından meydana gelen akut klinik bir tablodur. Maddenin yalnızca bir kere kullanıımasının ardından gelişebilecek madde ile ilişkili tek bozukluktur ve herkeste intoksikasyon gelişebilmektedir. Nikotin dışındaki diğer maddeler, ayırt edici intoksikasyon sendromları oluştururlar. Kişide, merkezi sinir sistemini etkileyen bir maddeyi kullanmasının ardından fiziksel belirtiler ve davranışsal veya psikolojik değişimler meydana gelir (26).

Madde Yoksunluğu: Yoksunluk semptomları, madde kullanıcısının beyninde madde yoğunluğunun azalması sonucunda gelişir ve kişide sıkıntı veya işlevsizlik yaratır. Bu semptomlar kullanılan maddeye göre değişmekle birlikte; bazı semptomlar birçok madde için ortaktır. Madde bağımlılarının büyük çoğunluğunda maddenin birden kesilmesi ile birlikte yoksunluk oluşurken, halüsinojenler gibi bazı maddeler bağımlıık yarattığı halde yoksunluğa yol açmaz. Yoksunluğun zamanı maddenin yarılanma ömrü ile ilişkilendirilir. Genellikle son doz alımının 12-24 saat sonrasında başlayan ve madde kullanma arzusunun eşlik ettiği yoksunluk semptomları birkaç günden uzun sürmemektedir (26).

Maddenin Yol Açtığı Diğer Bozukluklar: Maddeye bağlı gelişen bu etki, şiddetli seyretme potansiyeline sahip olup genelde geçici bir durum teşkil etmektedir; fakat madde suiistimali, ilacın veya şiddetli toksinlerin etkisiyle kalıcı merkezi sinir sistemi sendromları oluşturabilmektedir. DSM-V'te maddenin/ ilacın yol açtığı diğer bozukluklar; psikotik bozukluklar, bipolar ve ilişkili bozukluklar, depresif bozukluk, anksiyete bozukluğu, obsesif kompulsif ve ilişkili bozukluklar, uyku bozukluğu, cinsel disfonksiyon, deliryum ve nörolojik-bilişsel bozukluklar olarak tanımlanmışıı (8).

\section{Maddenin Yol Açtığı Psikotik Bozukluklar}

Madde kullanan bireylerde psikoz gelişme oranı normal popülasyona kıyasla daha yüksektir. Madde ile ilişkili bozuklukların prognozu ve tedavi başarııının psikoz gelişiminden olumsuz yönde etkilendiği bilinmektedir. Maddenin yol açtığı psikotik bozuklukların oluşum mekanizmalarının doğru açıklanması bu bozuklukların etiyolojilerinin daha iyi anlaşılmasını sağlar. Bununla birlikte, maddenin yol açtığı psikotik bozukluk ile birincil psikotik bozukluk ayrımının doğru yapılması bu vakaların değerlendirilmesinde en zor noktalardan birisidir. Literatürde alkol, kannabis, kokain ve inhalan gibi psikoaktif maddelerin psikotik bozukluklar ile ilişkisini kanıtlayan farklı çalışmalar mevcuttur (27).

Madde kullanım bozukluğu ve ruhsal bozukluk arasındaki ilişki oldukça karmaşıktır. Şekil 1'de gösterildiği üzere, psikotik bo- 


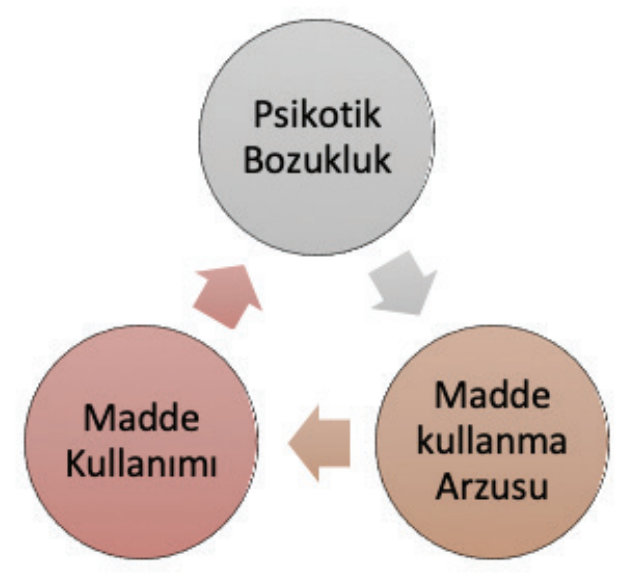

Şekil 1. Madde kullanım bozuklukları ve psikotik bozukluk arasındaki ilişki.

zukluk tanılı hastaların büyük bir bölümünde madde ile ilişkili bozukluklar gözlenebildiği gibi benzer şekilde, psikoaktif maddelerin yol açtığı bozuklukların gözlendiği bireylerde psikotik bozukluk gelişme riski de artmaktadır. Yapılan araştırmalar, alkol bağımlılarının 1/3'ünden fazlasında ve bütün madde bağımlılarının 1/2'sinden fazlasında ruhsal bozukluklar gözlendiğini bildirmektedir (28).

Birçok kullanıcı için, yoksunluk esnasında tamamen giderilebilen maddenin indüklediği psikotik semptomlar, ICD-10 (Uluslararası Hastalık Sınıflaması, 10. Revizyon) içerisinde psikoaktif maddenin veya maddelerin indüklediği psikotik bozukluklar olarak tanımlanmaktadır. Fakat yapılan son çalışmalar, madde aracılı psikotik bozukluk geçiren bazı hastalarda sonraki dönemlerde şizofreni gelişiminin beklenenden daha yüksek oranlarda olduğunu ortaya koymuştur. Niemi-Pynttari ve arkadaşları tarafından Finlandiya'da gerçekleştirilmiş bir çalışmada, kannabis, amfetamin ve alkolün indüklediği psikotik bozuklukların 3 yıl içerisinde şizofreni spektrum bozukluklarına dönüşüm oranlarının sırasıyla $\% 46, \% 30$ ve $\% 5$ olduğu belirlenmiştir (29).

\section{Maddenin Yol Açtığı Psikotik Bozuklukların Tanı Kriterleri}

DSM-V'e göre maddenin yol actığı psikotik bozuklukların tanı kriterlerinden sanrılar veya varsanılardan en az birinin varlığı karakteristik belirteç olarak kabul edilmektedir (8). Bununla birlikte gözlenen bu sanrı/varsanıların ilaç veya madde kullanımını takiben gelişmesi ve bu bahsi geçen madde veya ilacın karakteristik belirteç olarak kabul edilen sanrı/varsanı belirtilerini oluşturma durumu değerlendirilir. Ayrıca bu bulgulara paralel olarak bozukluğun deliryum esnasında gelişmiyor olması ve klinik olarak anlamlı sorunlara veya toplumsal alan ve iş hayatında işlevsizliklere sebebiyet vermesi de tanıya yardımcı olan faktörler arasındadır (8).

\section{Maddenin Yol Açtığı Psikotik Bozuklukların Risk Faktörleri} Maddenin yol açtığı psikozların yaygınlığı üzerindeki epidemiyolojik verilerin erişilebilirliği mümkün değilken; yoğun madde kullanımının ardından psikotik belirtiler tecrübe ettiğini bildirmiş kişiler üzerinde yapılan klinik araştırma sayısı azımsanmayacak ölçüdedir.

Çin'in Pekin ve Guangdong bölgelerinde 18 yaş ve üzerindeki metamfetamin kullanıcıları üzerinde yapılmış olan bir çalışmaya göre; metamfetamin kullanıcıları arasında metamfetamin ile ilişkili psikotik semptomların yaygın olduğu belirlenmiştir. Metamfetamine bağlı psikotik semptomların risk faktörleri arasında; yüksek doz ve uzun süreli metamfetamin kullanımı, eroin veya tütün kullanım hikayesi, depresyon veya anksiyete sorununun yer aldığı sonucuna varılmıştır. Bu bulgular; metamfetamin kullanan bireylerde kullanımı önleyici ve psikotik bozuklukları tedavi edici stratejilerin geliştirilmesinin önemini gözler önüne sermiştir (30). Roncero ve arkadaşlarının, indüklenmiş psikotik bozuklukların kokain kullanıcıları üzerindeki etkilerine dair yaptıkları çalışmada ise kokain kullanan bireylerin yaşamları boyunca en az bir defa psikotik semptom geçirme durumlarının \%29'dan \%75'e kadar yükselebildiği not edilmiştir (31).

Madde aracılı gelişen bu ve bunlara benzer bozuklukların risk faktörleri arasında; madde cinsi, kullanım süresi ve yaş, cinsiyet, genetik faktörler, ailede şizofreni hikayesi, uygulama yolu, doz, nörofizyolojik yatkınlık, beden kitle indeksi, psikiyatrik bozukluk eş tanısı ve birden fazla madde kullanımı yer almaktadır (31). Bütün maddelerin indüklenmiş psikoz oluşumunda risk teşkil etmesine rağmen aynı anda birden fazla madde kullanımının psikoz oluşumu için en güçlü risk faktörü olduğu belirtilmektedir (32).

\section{Maddenin Yol Açtığı Psikotik Bozuklukların Tedavisi}

Madde kötüye kullanımının yol açtığı tıbbî, sosyal ve psikolojik zararların indirgenmesinde en etkin araç tedavidir. Madde kullanımını sonlandırmak asıl hedef olsa da kullanım miktarı ve sıklığının azaltılabilmesi de doğacak problemlerin hafiflemesini sağlayabilmektedir (33).

Maddenin yol açtığı psikotik bozuklukların tedavisinde başlıca hedefler:

1) Madde kullanma arzusu ve madde kullanımının indirgenmesi,

2) Bireyin sağlığının ve işlevselliğinin düzeltilmesi,

3) Komplikasyon ve nüks risklerinin azaltılarak olası tehlikelerin önlenmesidir (34).

Bu amaçlar doğrultusunda güncel klinik olarak hem farmakolojik hem de bireyin psikososyal durumuna yardımcı olabilecek psikolojik danışmanlık ve rehabilitasyon hizmetleri uygulanmaktadır.

50'nin üzerinde yapılmış kontrollü çalışmadan varılan sonuca göre; madde ile ilişkili bozukluk ve mental bozukluk eş tanısında farklı disiplinlerin kullanıldığı bütüncül bir tedavi yaklaşımının uygulanmasının büyük önem taşıdığı görülmektedir. Madde kötüye kullanımı tedavi programı ve toplum ruh sağlığı merkezlerinin felsefi açıdan tedaviye yaklaşımları birbirlerinden ayrılsa da hastaların hem mental bozukluklarının hem de madde kullanımlarının aynı önemde tedavi edilmesi gerektiği 
mesajı, bu kliniklerdeki uzmanlar tarafından hastaya hissettirilmelidir. Madde kullanımı ve mental bozukluk eş tanısında başarılı bir tedavi, farmakoterapi, psikososyal tedavi ve madde kötüye kullanımı ile ilgili danışmanlık programlarının koordinasyonu ile mümkündür.

Maddenin yol açtığı psikotik bozuklukların farmakolojik tedavi uygulamaları arasında spesifik olarak kullanılan çeşitli ilaç grupları yer almaktadır.

McEvoy ve arkadaşlarının 1995 yılında yapmış oldukları çalışmalar sonucunda, yüksek etkili tipik antipsikotiklerin psikotik belirtilerin azaltılmasında etkin olmalarına rağmen hastaların madde kullanım oranlarını arttırdıkları belirlenmiştir (35). Bununla birlikte; düşük etkili tipik antipsikotiklerin madde kullanım oranlarını azaltmada başarılı olmalarına karşın; psikotik belirtilerin azaltılmasında yetersiz kaldıkları belirtilmiştir. Bunu takiben Green ve arkadaşları 1999 yılında yapmış oldukları çalışmada bu durumun nedeni olarak; yüksek etkili tipik antipsikotiklerin düşük etkili tipik antipsikotiklere göre mezokortikolimbik ödül yolağında daha yüksek seviyede dopamin antagonisti etkinliği gösteriyor olmalarını öne sürmüşlerdir (36).

Diğer taraftan, atipik antipsikotiklerin; dopamin reseptörü antagonizmasında seçici olmaları ve serotonin, noradrenalin ve histamin yolakları üzerindeki etkinlikleri sebebiyle maddenin yol açtığı psikotik bozuklukların tedavisinde tipik antipsikotiklerin yerine daha sıklıkla tercih edildikleri bilinmektedir. Atipik antipsikotik ilaçların antihistaminik etki mekanizmaları ile bireylerde uyku halinin oluşmasının yanı sıra; anksiyetede azal- ma gözlendiği ve özellikle $5-\mathrm{HT}_{2}$ reseptörleri üzerindeki antiserotoninerjik etki mekanizmaları ile kişilerin psikoaktif madde kullanımlarına yönelik takıntılı düşüncelerini gidermede daha başarılı olduğu da farklı çalışmalarda gösterilmiştir (8).

Atipik antipsikotiklerin, negatif semptomlar üzerinde daha etkili, ekstrapiramidal sistem yan etkilerinin daha az olması ve serotonin, histamin ve norepinefrin üzerinden de aktivite göstermeleri dolayısıyla tipik antipsikotik ilaçlara göre avantaj sağladıkları kaydedilmiştir (37).

\section{Tedavide Kullanılan Atipik Antipsikotikler}

Atipik antipsikotikler, klasik antipsikotiklere göre $D_{2}$ reseptörünü daha az bloke ederek işlev gösteren ve ayrıca diğer dopamin reseptörleri, serotonin (5-HT) reseptörleri ve çeşitli nörotransmitterler üzerinde de etkisi bulunan ilaç grubudur. Antipsikotik etkilerinin temeli, dopamin sistemi ile ilişkilendirilirken; antipsikotik etki ve yan etkide öncelikle serotonin olmak üzere diğer nörotransmitterlerin de rol oynadığı öngörülmektedir (38). Klozapin, risperidon, olanzapin, ketiapin, ziprasidon, aripiprazol, sülpirid bu grupta olmakla birlikte Tablo 2'de atipik antipsikotiklerin genel kullanım alanları ve Amerikan Gıda ve İlaç Dairesi (FDA) tarafından onay tarihleri özetlenmiştir.

\section{Klozapin}

Atipik antipsikotiklerin prototipi olan klozapin'in 1960'ların ortalarında etkili bir antipsikotik olduğu gözlenmiş fakat, 1974 yıIında Finlandiya'da Klozapin kullanmış 8 hastanın agranülositoz sonucu hayatını kaybetmesiyle birlikte rutin kullanımı sonlandırılmıştır (39). 1990'da ise ekstrapiramidal sistem yan etkileri

Tablo 2. Atipik Antipsikotik İlaçların Kullanım Alanları (37)

\begin{tabular}{|c|c|c|}
\hline $\begin{array}{l}\text { Atipik Antipsikotik } \\
\text { İlaçlar }\end{array}$ & Kullanım Alanları & FDA Onayı \\
\hline Klozapin & $\begin{array}{l}\text { Tedaviye dirençli şizofrenik hastaların tedavisi } \\
\text { Klasik antipsikotik kullanımı sonucu ekstrapiramidal yan etki gelişen hastalarda tedavi }\end{array}$ & 1990 \\
\hline Risperidon & $\begin{array}{l}\text { Uzun süreli şizofreni tedavisi } \\
\text { Bipolar bozuklukla iliş̧ili manik durumların kısa süreli tedavisi }\end{array}$ & 1993 \\
\hline Olanzapin & Şizofreni grubu psikotik bozuklukların tedavisi & 1996 \\
\hline Ketiapin & Akut şizofreni ve şizoaffektif bozukluk tedavisi & 1997 \\
\hline Ziprasidon & $\begin{array}{l}\text { Şizofreni ve bipolar bozukluk, } \\
\text { Travma sonrası stres bozukluğu ve depresyon tedavileri }\end{array}$ & 2001 \\
\hline Aripiprazol & $\begin{array}{l}\text { Akut psikoz, şizofreni tedavileri } \\
\text { Bipolar bozukluk ilişkili manik durumların stabilizasyonu }\end{array}$ & 2002 \\
\hline Paliperidon & Şizofreni ve şizoaffektif bozukluk tedavisi & 2007 \\
\hline Asenapin & $\begin{array}{l}\text { Şizofreninin idame tedavisi } \\
\text { Akut bipolar bozukluk tedavisi }\end{array}$ & 2009 \\
\hline Amisülpirid & Akut psikotik hastalıkların tedavisi & 2020 \\
\hline Sülpirid & Akut psikoz, şizofreni ve majör depresif bozukluk tedavisi & YOK \\
\hline
\end{tabular}


ve tardif diskinezi oluşturmaları sebebiyle tipik antipsikotikleri tolere etmekte güçlük çeken şizofreni hastaları için FDA tarafından onaylanmıştır. Pozitif semptomları tedavi ettiği gibi, psikozun negatif ve defisit semptomlarının tedavisinde de oldukça başarılıdır (38).

Etki mekanizması: Klozapin, santral sinir sisteminde başlıca $D_{1}$ ve $D_{4}$ tipi dopamin reseptörlerini antagonize etmektedir. Ekstrapiramidal sistem yan etkilerinin klasik antipsikotiklere göre daha az olması $D_{2}$ tipi dopamin reseptörleri üzerindeki etkisinin daha düşük olması ile açıklanmaktadır. Bununla birlikte, dirençli şizofreni vakalarında klozapin'in tedavi başarısının serotonin $5-\mathrm{HT}_{2}$ reseptörlerini antagonize etmesine dayandığı düşünülmektedir (8).

\section{Risperidon}

Klozapin'in ardından ABD'de FDA tarafından Aralık 1993'te şizofreninin akut tedavisi için onaylanmış atipik antipsikotiktir. Risperidon'un devamlı kullanımı hastalığın nüksünü engellediği için, Mart 2002'de FDA tarafından şizofreninin uzun süreli tedavisinde onaylanmıştır. Bunun yanı sıra; oral risperidon bipolar maninin kısa süreli tedavisinde tek başına ya da lityum veya valproat ile birlikte kullanılmak üzere Aralık 2003'te onay almıştır (40).

Etki mekanizması: Serotonin $5-\mathrm{HT}_{2}$ ve dopamin $\mathrm{D}_{2}$ reseptörlerine yüksek afinite göstermektedir. Dopamin $D_{2}$ reseptörlerinin antagonize edilmesi ile, şizofreninin pozitif belirtileri arasında yer alan halüsinasyon, hatalı konuşma ve delüzyonun iyileşmesine katkı sağlanmaktadır. Serotonin ve dopamin reseptörlerinin her ikisine karşı antagonist etki göstermesinin, şizofreninin negatif ve pozitif belirtilerini iyileştirmesini ve ekstrapiramidal sistem yan etkilerinin oluşmamasını sağladığı düşünülmektedir (40).

\section{Sülpirid}

Bazı özellikleri ile tipik antipsikotiklere benzemekle birlikte özellikle $D_{2}$ reseptörlerine karşı seçici afinite göstermesi dolayısıyla atipik antipsikotikler altında sınıflandırılmıştır. Uzun süreli kullanımında dopaminerjik reseptörler üzerinde aşırı duyarlılık yaratmaması veya çok az yaratması kullanımı açısından avantaj sağlamaktadır (41).

Etki mekanizması: Antipsikotik etkisi merkezi sinir sisteminde postsinaptik dopamin $\mathrm{D}_{2}$ reseptörlerini selektif olarak antagonize etmesiyle gerçekleşmektedir.

\section{Amisülpirid}

Amisulpirid, $D_{2} / D_{3}$ dopamin reseptörlerine seçiciliği ve serotonin $5-\mathrm{HT}_{2 \mathrm{~A}}$ reseptörlerine afinitesi nedeniyle atipik antipsikotikler arasında yer alan önemli bir ilaçtır (37).

Etki Mekanizması: Tipik ve atipik antipsikotiklerden ayrılarak, a-adrenerjik, kolinerjik ve histamin $\mathrm{H}_{1}$ reseptörlerine karşı afinitesi bulunmamakla birlikte dopamin $D_{2}$ ve $D_{3}$ reseptörlerine selektif afinite göstermesi dolayısıyla şizofreninin pozitif ve negatif belirtileri üzerinde güçlü etkinlik gösterir (37).

\section{Ketiapin}

Kimyasal yapı olarak klozapine benzeyen bir atipik antipsikotiktir. Bu sebeple klozapine benzer biçimde şizofreninin pozitif ve negatif belirtileri üzerinde etkinlik gösterirken; ekstrapiramidal sistem yan etkilerine yol açmamaktadır. Ketiapin'in hematolojik parametreler üzerinde değişikliğe yol açmayan bir atipik antipsikotik olması, şizofreni tedavisinde ilk tercih edilen ilaç konumunda yer almasını sağlamaktadır (42).

Etki mekanizması: Orta derecede dopamin $\mathrm{D}_{2}$ ve güçlü derecede serotonin $5-\mathrm{HT}_{2}$ reseptör antagonisti olarak etki gösteren bir atipik antipsikotiktir. Ketiapin; serotonin 5- $\mathrm{HT}_{1 \mathrm{~A}}$, histamin $H_{1}$, adrenerjik a1-, adrenerjik a2- ve dopamin $D_{1}$ reseptörlerini antagonize ederken; kolinerjik, muskarinik ve benzodiazepin reseptörlerine karşı etki göstermemektedir.

\section{Olanzapin}

Kimyasal yapı ve etki mekanizması bakımından klozapin'e benzeyen olanzapin, FDA tarafından Ekim 1996'da şizofreni tedavisi için; Mart 2000'de akut bipolar mani tedavisinde tek başına kullanılmak üzere onaylanmıştır. Reseptör afinite profili oldukça geniş olup mezolimbik dopaminerjik aktiviteyi selektif olarak etkiler (43).

Etki Mekanizması: Olanzapin a1-, dopamin, muskarinik, histamin $\mathrm{H}_{1}$ - ve serotonin $5-\mathrm{HT}_{2}$ reseptörlerine bağlanan bir atipik antipsikotiktir. Antipsikotik etkisi, dopamin ve serotonin $5-\mathrm{HT}_{2}$ reseptörlerini antagonize etmesiyle ilişkilendirilmiştir. Olanzapin'in dopamin D2 reseptörlerine göre $5-\mathrm{HT}_{2}$ reseptörleri üzerindeki afinitesinin yaklaşık olarak 2 kat daha fazla olması; ekstrapiramidal sistem yan etkilerini azaltmaktadır (43).

\section{Ziprasidon}

FDA tarafından 2001 yılında onaylanmış olan Ziprasidon benzisotiyazol piperazin grubuna ait bir atipik antipsikotik ilaçtır (44). Serotonin ve norepinefrin taşıyıcıları için yüksek bir afiniteye sahip olma açısından da diğer atipik antipsikotiklerden farklılık göstermektedir.

Etki Mekanizması: Atipik antipsikotikler arasında ziprasidon, serotonin 5- $\mathrm{HT}_{2 \mathrm{~A}}$ reseptörlerine karşı ters agonist, 5- $\mathrm{HT}_{1 \mathrm{~A}}$ reseptörlerine karşı agonist ve $5-\mathrm{HT}_{1 \mathrm{D}}$ ve $5-\mathrm{HT}_{2 \mathrm{C}}$ reseptörlerine karşı antagonist aktivite sergileyebilen benzersiz bir moleküldür (44). 5- $\mathrm{HT}_{1 \mathrm{~A}}$ reseptörleri üzerindeki agonist etkisi dolayısıyla kortikal dopamin salınımını artırarak $\mathrm{D}_{2}$ antagonistlerinin yol açtığı ekstrapiramidal yan etkilerin azaltılmasını sağlar (44).

\section{Aripiprazol}

FDA tarafından, 15 Kasım 2002'de şizofreni tedavisi için; 2003'te şizofreninin idame tedavisi için, 29 Eylül 2004'te akut bipolar mani tedavisi için ve 7 Mart 2005'te bipolar bozukluğun idame tedavisi için onaylanmıştır. Diğer antipsikotik ilaçlardan ayrılan ve dopamin sistemi stabilizanı olarak isimlendirilen yeni bir atipik antipsikotik sınıfının ilk üyesi olan Aripiprazol, parsiyel dopamin agonistidir. Şizofreninin negatif ve kognitif belirtileri üzerinde iyileşme sağlarken, ekstrapiramidal sistem yan etkileri diğer antipsikotik ilaçlara oranla daha az gözlenmektedir (45). 
Etki Mekanizması: Aripiprazol, dopamin $D_{2}$ ve serotonin $5-\mathrm{HT}_{1 \mathrm{~A}}$ reseptörleri üzerinde parsiyel agonist etki gösterirken, serotonin $5-\mathrm{HT}_{2 \mathrm{~A}}$ reseptörleri üzerinde antagonist etki göstermektedir. Dopamin D2 reseptörlerine oranla serotonin $5-\mathrm{HT}_{1 \mathrm{~A}}$ ve $5-\mathrm{HT}_{2 \mathrm{~A}}$ reseptörlerine daha yüksek afinite göstermesi daha az ekstrapiramidal sistem yan etkilerine sebep olmasını açıklamaktadır. Ayrıca dopamin $\mathrm{D}_{3}, \mathrm{D}_{4}$, serotonin $5-\mathrm{HT}_{2}, 5-\mathrm{HT}_{7}, \mathrm{a}-1$ adrenerjik ve histamin $\mathrm{H}_{1}$ reseptörlerini de etkilemesi sebebiyle, aripiprazol, ortostatik hipotansiyon ve somnolans gibi etkiler oluşturmaktadır (45).

\section{Paliperidon}

Atipik antipsikotikler sınıfında yer alan ve risperidon'un ana aktif metaboliti olan paliperidon'un uzatılmış salımı, FDA tarafından Aralık 2006'da yetişkinler için şizofreninin akut tedavisinde ve Nisan 2007 'de şizofreninin idame tedavisi için onaylanmıştır. Risperidon'a benzer şekilde ekstrapiramidal sistem yan etkilerine yol açmadan, şizofreninin negatif ve pozitif semptomlarını gidermektedir. Şizofreni hastalarında paliperidon kullanımı, hastalar üzerinde stabilitede ve hastaların işlevselliğinde artış sağlamaktadır (46).

Etki Mekanizması: Santral dopamin $\mathrm{D}_{2}$ ve serotonin $5-\mathrm{HT}_{2 \mathrm{~A}}$ reseptörlerini bloke ederek şizofreninin pozitif ve negatif semptomlarını gidermektedir. a1 ve a2 adrenerjik reseptörlerini antagonize etmesi sonucunda ortostatik hipotansiyon gibi yan etkiler oluşturmaktadır. Paliperidon, histamin $\mathrm{H} 1$ reseptörleri üzerine antagonist etki gösterirken; kolinerjik veya $\beta$-adrenerjik reseptörlere afinite göstermemektedir (46).

\section{Asenapin}

FDA tarafından Ağustos 2009'da yetişkinler için şizofreni ve bipolar I bozukluğun akut tedavisi için onaylanan asenapin, Ağustos 2010'da şizofreninin idame tedavisi ve bipolar I bozukluk için kullanılmakta olan lityum ve valproat'a ek olarak akut tedavide onaylanmıştır (47). 31 Ocak 2013 tarihinde, Türkiye'de şizofreni ve bipolar bozukluk tedavisi için ruhsat almıştır.

Etki mekanizması: Dopamin $\mathrm{D}_{2}$ ve serotonin $5-\mathrm{HT}_{2 \mathrm{~A}}$ reseptörleri üzerindeki antagonist etkisi şizofreni tedavisindeki aktivitesi ile ilişkilendirilmektedir. Asenapin'in serotonin 5- $\mathrm{HT}_{1 \mathrm{~A}}, 5-\mathrm{HT}_{1 \mathrm{~B}}$, $5-\mathrm{HT}_{2 \mathrm{~A}}, 5-\mathrm{HT}_{2 \mathrm{~B}}, 5-\mathrm{HT}_{2 \mathrm{C}}, 5-\mathrm{HT}_{5}, 5-\mathrm{HT}_{6}$ ve $5-\mathrm{HT}_{7}$, dopamin $\mathrm{D}_{1}, \mathrm{D}_{2}$, $D_{3}$ ve $D_{4}$, a1-, a2- adrenerjik ve histamin $H_{1}$ reseptörlerine karşı afinite gösterdiği belirlenmiştir. Histamin $\mathrm{H}_{2}$ reseptörlerine karşı afinitesi orta seviyedeyken; muskarinik reseptörlere bağlanmamaktadır. Şizofreninin negatif semptomlarını iyileştirmesi, serotonin reseptörlerine karşı antagonist etki göstermesiyle ilişkilendirilmiştir. Asenapin, a-1-adrenerjik reseptörlerini antagonize etmesi sebebiyle kullanıma bağlı ortostatik hipotansiyon, baş dönmesi ve taşikardi gibi yan etkiler gözlenebilir (47).

\section{TARTIŞMA}

Maddenin yol açtığı psikotik bozukluk tanısı için, madde kullanım öyküsünden önce psikotik bozukluk belirtilerinin gelişmemesi ve psikotik bozukluk belirtilerinin madde kullanımının ardından gelişmesi gerekmektedir. Sanrılar ve/veya varsanılar olarak belirtiler gösteren bu bozukluk, kişide klinik olarak anlam-
Iı sorunlara veya toplumsal ve çalışma hayatında işlevsizliklere yol açmaktadır (9). Madde kullanıcılarının normal popülasyon ile psikoz gelişme yaygınlığı açısından kıyaslanması sonucunda, madde kullanımının psikotik bozukluklar için bir risk faktörü olduğu belirlenmiştir. Madde ile ilişkili bozuklukların etkin biçimde tedavi edilebilmesi için, öncelikli olarak doğru teşhisin koyulması gerekmektedir. Maddenin yol açtığı psikotik bozukluğun ve birincil psikotik bozukluk ayrımının yapılabilmesi, hastalığın prognozunu ve tedavisini birinci dereceden etkilemektedir.

Alkol, kannabis, kokain, inhalan ve amfetamin kullanımının psikotik bozukluk ile ilişkisini kanıtlayan çeşitli çalışmalar literatürde mevcuttur. 2015 yılında yapılan bir araştırmaya göre madde aracılı psikoz geçiren kişilerin \%23'ünün takip eden 3 yıl içerisinde şizofreni tanısı aldığı gösterilmiş olup (11), farklı araştırmalarda madde kullanan kişilerde ileri dönemlerde kronik psikotik bozuklukların geliştiği kaydedilmiştir (48). Özellikle kannabisin indüklediği psikoz tanılarının \%50'ye yaklaşan oranda şizofreniye dönüştüğü gözlemlenmiştir. Bunların yanı sıra, amfetamin, opioid ve alkolün yol açtığı psikozların sırasıyla; \%50; \%30 ve \%24'e yakın oranda şizofreniye dönüştüğü bildirilmiştir (48).

Madde kötüye kullanımının yol açtığı tıbbî, sosyal ve psikolojik zararların indirgenmesinde en etkin araç bütüncül yaklaşımların kullanılarak hem madde aracılı gelişen psikotik bozuklukların hem de madde kullanma arzusunun hedef alındığı tedavi yöntemleridir.

Yüksek etkili tipik antipsikotikler, psikotik belirtilerin azaltılmasında etkin olmalarına karşın, bireylerin madde kullanım oranlarını arttırmış olmaları ve düşük etkili tipik antipsikotiklerin madde kullanım oranlarını azaltmada etkin olmalarına rağmen, psikotik belirtilerin azaltılmasında yetersiz kalmaktadırlar. Bunun nedeni mezokortikolimbik ödül yolağında yüksek etkili tipik antipsikotiklerin düşük etkili tipik antipsikotiklere göre daha yüksek düzeylerde dopamin antagonist aktivitesi sergilemesidir. Bu sebeplerle tipik antipsikotik ilaçlar, maddenin yol açtığı psikotik bozukluk tedavisinde tercih edilmemektedir. Şizofreni tedavisinde ilk geliştirilen ilaç grubu olan tipik antipsikotiklerin yol açtığı yan etkilerin hastaların ilaç uyumunu olumsuz etkilemesi sebebiyle atipik antipsikotikler geliştirilmiştir. Tipik antipsikotiklere göre yan etkilerin daha iyi tolere edilebildiği atipik antipsikotikler, dopamin reseptörüne seçici antagonist etki göstermelerinin yanı sıra, serotonin, noradrenalin ve histamin reseptörleri üzerinde de aktivite göstermeleri nedeniyle, maddenin yol açtığı psikotik bozukluğun farmakolojik tedavisinde birinci sırada tercih edilen ilaç grubudur (49).

Atipik antipsikotiklerin, maddenin yol açtığı psikotik bozukluk tedavisinde tipik antipsikotiklere üstünlüklerinin sebepleri; tipik antipsikotikler kadar pozitif semptomları etkin biçimde iyileştirmeleri, negatif semptomları tipik antipsikotikler kadar veya daha etkin iyileştirmeleri, antidepresan veya duygu durum dengeleyici etkinlik göstermeleri, saldırganlık ve dürtüselliğin giderilmesinde başarılı olmaları, ekstrapiramidal sistem yan etkilerinin daha az olması, intihar eğilimini azaltmaları ve bilişsel gelişimi desteklemeleri şeklinde sıralanabilir (50). 


\section{SONUÇ}

Sonuç olarak, dünya genelinde giderek artan madde kullanımı ve buna bağlı olarak toplumda giderek yaygınlaşan madde ile ilişsili bozukluklar medikal, psikolojik ve sosyal açıdan ciddi sorunlara yol açmaktadır. Madde ile ilişkili olarak başlayan bozukluğun daha ileri dönemlerde şizofreni veya bipolar bozukluk gibi önemli psikotik hastalıklara dönüşme olasılığı bu bozuklukların tanı ve tedavilerinin doğru ve etkin bir şekilde yapılması gerekliliğini gözler önüne sermektedir. Bu açıdan ele alındığında en etkin tedavi yöntemi olarak hem kişinin madde kullanma arzusunun hem de kullanılan madde ile birlikte gelişen psikotik bozukluk durumunun hedeflendiği farmakoterapi, psikososyal yaklaşımlar veya elektrokonvulzif tedaviyi içeren bütüncül tedavi programlarının uygulanması gerekmektedir. Maddenin yol açtığı psikotik bozukluğun farmakolojik tedavisinde atipik antipsikotikler ekstrapiramidal sistem yan etki profillerinin diğer grup ilaçlara göre daha az olması ve madde kullanma arzusu üzerindeki etkinliklerinin daha fazla olması sebebiyle birinci sırada tercih edilen ilaç grubudur.

Maddenin yol açtığı psikotik bozuklukların risk faktörlerinin de göz önüne alınmasıyla hastalığın önlenmesi ve erken tanı ve tedavi uygulamaları sonucunda hastalığın ciddi boyutlara ulaşmadan tedavi edilebilmesi mümkündür.

\section{Hakem Değerlendirmesi: Dış bağımsız.}

Yazar Katkıları: Fikir - M.K., G.K.; Veri Toplanması ve/veya İşlemesi M.K., G.K.; Analiz ve/veya Yorum - M.K., G.K., E.Ş., E.S.I.; Literatür Taraması - M.K., G.K., E.Ş., E.S.I.; Yazan - M.K., G.K.; Eleştirel İnceleme - E.S.I., E.Ş.

Çıkar Çatışması: Yazarlar çıkar çatışması bildirmemişlerdir.

Finansal Destek: Yazarlar bu çalışmada finansal destek almadıklarını beyan etmişlerdir.

Peer-review: Externally peer-reviewed.

Author Contributions: Concept - M.K., G.K., Data Collection and/or Processing - M.K., G.K., Analysis and/or Interpretation - M.K., G.K., E.Ş., E.S.I.; Literature Search - M.K., G.K., E.Ş., E.S.I.;Writing - M.K., G.K.; Critical Reviews - E.S.I.', E.Ş.

Conflict of Interest: The authors have no conflict of interest to declare.

Financial Disclosure: The authors declared that this study has received no financial support.

\section{KAYNAKLAR}

1. Lewis A. The Psychopathology Of Insight. Br J Med Psychol 1934; 14(4): 332-48. [CrossRef]

2. Amador XF, Strauss DH, Yale SA, Gorman JM. Awareness of illness in schizophrenia. Schizophr Bull 1991; 17(1): 113-32. [CrossRef]

3. Mueser KT, Gingerich S. Treatment of co-occurring psychotic and substance use disorders. Soc Work Public Health 2013; 28(3-4): 424-39. [CrossRef]
4. Kessler RC, Wai TC, Demler O, Walters EE. Prevalence, severity, and comorbidity of 12-month DSM-IV disorders in the National Comorbidity Survey Replication. Arch Gen Psychiatry 2005; 62(6): 617-27. [CrossRef]

5. Rush B, Koegl CJ. Prevalence and profile of people with co-occurring mental and substance use disorders within a comprehensive mental health system. Can J Psychiatry 2008; 53(12): 810-21. [CrossRef]

6. Hasin DS, Stinson FS, Ogburn E, Grant BF. Prevalence, Correlates, Disability, and Comorbidity of DSM-IV Alcohol Abuse and Dependence in the United States: Results From the National Epidemiologic Survey on Alcohol and Related Conditions. Arch Gen Psychiatry 2007; 64(7): 830-42. [CrossRef]

7. Akerman SC, Brunette MF, Noordsy DL, Green Al. Pharmacotherapy of Co-Occurring Schizophrenia and Substance Use Disorders. Curr Addict Rep 2014; 1(4): 251-60. [CrossRef]

8. American Psychiatric Association: Diagnostic and Statistical Manual of Mental Disorders: Diagnostic and Statistical Manual of Mental Disorders, Fifth Edition. Arlington, VA: American Psychiatric Association, 2013. p.481-585. [CrossRef]

9. Adinoff B. Neurobiologic processes in drug reward and addiction. Harv Rev Psychiatry 2004; 12(6): 305-20. [CrossRef]

10. Chen WL, Hsieh CH, Chang HT, Hung CC, Chan CH. The epidemiology and progression time from transient to permanent psychiatric disorders of substance-induced psychosis in Taiwan. Addict Behav 2015; 47: 1-4. [CrossRef]

11. Dilbaz N, Akvardar Y, Berkman K, Oral G, Uluğ B, Uzbay T, et al. Madde Bağımlıı̆̆ı Tanı ve Tedavi Kılavuzu El Kitabı. T. C. Sağlık Bakanlığı Sağlık Hizmetleri Genel Müdürlüğü, BÖLÜM 4: Alkol Kullanım Bozukluğu. 2012. p.105-23.

12. Wang HR, Woo YS, Bahk WM. Caffeine-induced psychiatric manifestations: A review. Int Clin Psychopharmacol 2015; 30(4): 179-82. [CrossRef]

13. Hedges BDW, Woon FL, Hoopes SP. Caffeine-Induced Psychosis. CNS Spectr 2009; 14(3): 127-9. [CrossRef]

14. Lucas PB, Pickar D, Kelsoe J, Rapaport M, Pato C, Hommer D. Effects of the acute administration of caffeine in patients with schizophrenia. Biol Psychiatry 1990; 28: 35-40. [CrossRef]

15. Sharma P, Murthy $P$, Bharath MMS. Chemistry, metabolism, and toxicology of cannabis: Clinical implications. Iran J Psychiatry 2012; 7(4): 149-56.

16. United Nations Office on Drugs and Crime (UNODC). World Drug Report 2019 Booklet 5: Cannabis And Hallucinogens. (United Nations publication, Sales No. E.19.XI.8.p.9-49. Available from: https:// wdr.unodc.org/wdr2019/

17. Greenfield SF, Back SE, Lawson K, Brady KT. Substance Abuse in Women. Psychiatr Clin North Am 2010; 33(2): 339-55. [CrossRef]

18. Garcia-Romeu A, Kersgaard B, Addy PH. Clinical applications of hallucinogens: A review. Exp Clin Psychopharmacol 2016; 24(4): 229-68. [CrossRef]

19. United Nations Office on Drugs and Crime (UNODC). World Drug Report 2019 Booklet 5: Cannabis And Hallucinogens. United Nations publication, Sales No. E.19.XI.8.p.51-73. Available from: https://wdr.unodc.org/wdr2019/

20. Dilbaz N, Akvardar Y, Berkman K, Oral G, Uluğ B, Uzbay T, et al. Madde Bağımlıı̆ı Tanı ve Tedavi Kılavuzu El Kitabı. T. C. Sağlık Bakanlığı Sağlık Hizmetleri Genel Müdürlüğü, BÖLÜM 9: Uçucularin Kullanimina Bağli Ruhsal Ve Davranişsal Bozukluklar. 2012. p.15767.

21. Robinson SM, Adinoff B. The classification of substance use disorders: Historical, contextual, and conceptual considerations. Behav Sci (Basel) 2016; 6(3): 1-23. [CrossRef] 
22. Frese WA, Eiden K. Opioids: Nonmedical use and abuse in older children. Pediatrics in Review 2011; 32(4): e44-e52. [CrossRef]

23. United Nations Office on Drugs and Crime (UNODC). World Drug Report 2018 Booklet 1: Executive Summary and Policy Implications. United Nations publication, Sales No. E.18.XI.9.p.1-32. Available from: https://www.unodc.org/wdr2018/ [CrossRef]

24. Hasin DS, Stinson FS, Ogburn E, Grant BF. Prevalence, correlates, disability, and comorbidity of DSM-IV alcohol abuse and dependence in the United States: Results from the national epidemiologic survey on alcohol and related conditions. Arch Gen Psychiatry 2007; 64(7): 830-42. [CrossRef]

25. Kluwe-Schiavon B, Viola TW, Sanvicente-Vieira B, Lumertz FS, Salum GA, Grassi-Oliveira R, et al. Substance related disorders are associated with impaired valuation of delayed gratification and feedback processing: A multilevel meta-analysis and meta-regression. Neuroscience and Biobehavioral Reviews 2020; 108: 295307. [CrossRef]

26. Dilbaz N, Akvardar Y, Berkman K, Oral G, Uluğ B, Uzbay T, et al. Madde Bağımlıı̆ı Tanı ve Tedavi Kılavuzu El Kitabı. T. C. Sağlık Bakanlığı Sağlık Hizmetleri Genel Müdürlüğü, Madde Kullanımı İle Iliş̧kili Bozukluklar (DSM-IV-TR'ye Göre). 2012. p.22-45.

27. Prom-Wormley EC, Ebejer J, Dick DM, Bowers MS. The genetic epidemiology of substance use disorder: A review. Drug Alcohol Depend 2017; 180: 241-59. [CrossRef]

28. Balhara YPS, Kuppili PP, Gupta R. Neurobiology of Comorbid Substance Use Disorders and Psychiatric Disorders: Current State of Evidence. J Addict Nurs 2017; 28(1): 11-26. [CrossRef]

29. Niemi-Pynttari JA, Sund R, Putkonen H, Vorma H, Wahlbeck K, Pirkola SP. Substance-Induced Psychoses Converting Into Schizophrenia: A Register-Based Study of 18,478 Finnish Inpatient Cases. J Clin Psychiatry 2013; 74(1): e94-e99. [CrossRef]

30. Su MF, Liu MX, Li JQ, Lappin JM, Li SX, Wu P, et al. Epidemiological characteristics and risk factors of methamphetamine-associated psychotic symptoms. Front Psychiatry 2018; 9: 489. [CrossRef]

31. Roncero C, Ros-Cucurull E, Daigre C, Casas M. Prevalence and risk factors of psychotic symptoms in cocaine-dependent patients. Actas Esp Psiquiatr 2012; 40(4): 187-97.

32. Rognli EB, Berge J, Håkansson A, Bramness JG. Long-term risk factors for substance-induced and primary psychosis after release from prison. A longitudinal study of substance users. Schizophr Res 2015; 168(1-2): 185-90. [CrossRef]

33. Straussner SLA, Hanson M, Seiger BH, Davis J, et al. Assessment and Treatment of Clients with Substance Use Disorders: An Overview. In Shulamith Lala Ashenberg Straussner editor, Clinical work with substance-abusing clients ( 2 nd ed.). Guilford Publications. 2014.p.3-35.

34. Murty P, Chand P. Treatment of dual diagnosis disorders. Curr Opin Psychiatry 2012; 25(3): 194-200. [CrossRef]
35. McEvoy JP, Freudenreich O, Levin ED, Rose JE. Haloperidol increases smoking in patients with schizophrenia. Psychopharmacology (Berl) 1995; 119(1); 124-6. [CrossRef]

36. Green Al, Zimmet S V., Strous RD, Schildkraut JJ. Clozapine for comorbid substance use disorder and schizophrenia: Do patients with schizophrenia have a reward-deficiency syndrome that can be ameliorated by clozapine? Harvard Review of Psychiatry 1999; 6(6): 287-96. [CrossRef]

37. Marin-Mayor M. Atypical Antipsychotic Drugs in Dual Diagnosis Patients: A Review. Int J Neurol Neurother 2015; 2: 1-13. [CrossRef]

38. Duran A. Psikiyatride İlaçla Tedavi. In: Türkiye'de Sık Karşılaşılan Psikiyatrik Hastalıklar. I.Ü.Cerrahpaşa Tıp Fakültesi Sürekli Tıp Eğitimleri Etkinlikleri Sempozyum Dizisi No:62. 2008. p.275-302.

39. Hippius $\mathrm{H}$. The history of clozapine. Psychopharmacology (Berl) 1989; 99: S3-S5. [CrossRef]

40. Chopko TC, Lindsley CW. Classics in Chemical Neuroscience: Risperidone. ACS Chemical Neuroscience 2018; 9(7): 1520-9. [CrossRef ]

41. Caley CF, Weber SS. Sulpiride: An antipsychotic with selective dopaminergic antagonist properties. Ann Pharmacother 1995; 29(2): 152-60. [CrossRef]

42. Lieberman JA, Scott Stroup T, McEvoy JP, Swartz MS, Rosenheck RA, Perkins DO, et al. Effectiveness of antipsychotic drugs in patients with chronic schizophrenia. N Engl J Med 2005; 353(12): 1209-23. [CrossRef]

43. Tamminga CA, Lahti AC. The new generation of antipsychotic drugs. In: International Clinical Psychopharmacology 1996; 11(Suppl 2): 73-6. [CrossRef]

44. Masand PS, Nemeroff CB, Newcomer JW, Lieberman JA, Schatzberg AF, Weiden PJ, et al. From Clinical Research to Clinical Practice: A 4-Year Review of Ziprasidone. CNS Spectrums. Cambridge University Press; 2005; 10 (S17): 1-20. [CrossRef]

45. Prommer E. Aripiprazole: A New Option in Delirium. Am J Hosp Palliat Med 2017; 34(2): 180-5. [CrossRef]

46. Corena-McLeod M. Comparative pharmacology of risperidone and paliperidone. Drugs R D 2015; 15(2): 163-74. [CrossRef]

47. Vieta E, Montes JM. A Review of Asenapine in the Treatment of Bipolar Disorder. Clin Drug Investig 2018; 38(2): 87-99. [CrossRef]

48. Starzer MSK, Nordentoft M, Hjorthøj C. Rates and predictors of conversion to schizophrenia or bipolar disorder following substance-induced psychosis. Am J Psychiatry 2018; 175(4): 343-50. [CrossRef]

49. Green Al, Noordsy DL, Brunette MF, O'Keefe C. Substance Abuse and Schizophrenia: Pharmacotherapeutic Intervention. J Subst Abuse Treat 2008; 34(1): 61-71. [CrossRef]

50. Meltzer HY. Update on Typical and Atypical Antipsychotic Drugs. Annu Rev Med 2013; 64: 393-406. [CrossRef] 